\title{
STRESS ANALYSIS OF STICK REINFORCED GRANITE-PERIWINKLE CONCRETE SLAB UNDER UNIFORMLY DISTRIBUTED LOAD
}

\author{
Ibearugbulem O. $\mathbf{M}^{1}$, Ezeh J. $\mathrm{C}^{2}$, Inock E. $\mathrm{U}^{3}$, Obiekwe M. $\mathrm{O}^{4}$, Nwadike A. $\mathbf{N}^{5}$ \\ ${ }^{I}$ Doctor, Civil Engineering, Federal University of technology, Owerri, Imo State, Nigeria \\ ${ }^{2}$ Associate Professor, Civil Engineering, Federal University of technology, Owerri, Imo State, Nigeria \\ ${ }^{3}$ Civil Engineering, Federal University of technology, Owerri, Imo State, Nigeria \\ ${ }^{4}$ Civil Engineering, Federal University of technology, Owerri, Imo State, Nigeria \\ ${ }^{5}$ Civil Engineering, Federal University of technology, Owerri, Imo State, Nigeria
}

\begin{abstract}
This research work aims at providing alternative materials for coarse aggregate and steel reinforcement in concrete slab making in other to enhance affordable housing delivery. The materials were chosen based on their cheap cost and availability compared to the conventional materials. The long haulage distances and costly nature of granite has lead to Periwinkle shells being used in the riverine (Niger-Delta) areas of Nigeria to wholly or partially replace granite in concrete, while Owa stick (Jaundea Pinnata) has been used for decades in reinforcing earthen houses. This paper reports the stress resistance of owa stick reinforced grano-periwinkle concrete slab compared with steel reinforced and plain grano-periwinkle concrete slab when subjected to uniformly distributed load. The mix ratio of 1:2:2 was used for the concrete; the ratio of 1:1 was used for granite and periwinkle shells with a water-cement ratio of 0.5. Concrete cubes were casted and used in testing for compressive strength. Slabs of 500x500x100mm were also used to test for the maximum flexural stress under uniformly distributed load with two sets of reinforcement spacing, 90mm and 150mm. The slabs were simply-supported (ssss) on all the sides. The 28-day compressive strength and density of the concrete was found to be $19.932 \mathrm{~N} / \mathrm{mm} 2$ and $2617.48 \mathrm{~kg} / \mathrm{m} 3$. From this study it can be concluded that owa stick has elastic properties which helps in improving the tensile strength of concrete, though in comparison, steel is still preferred, but the stress resistance of owa stick reinforced concrete slab was more than that of plain concrete with the gain in stress of $25.30 \%$ at $90 \mathrm{~mm} \mathrm{c} / \mathrm{c}$ and a loss of $16.87 \%$ at $150 \mathrm{~mm} \mathrm{c/c}$. Also, owa stick reinforced slabs had more than 50\% flexural stress resistance when compared to steel reinforced slabs. Also, while plain concrete slab failed in brittle, owa stick reinforced concrete did not.
\end{abstract}

Keywords: Periwinkle, granite, aggregate, concrete, owa stick (Jaundea Pinnata), flexural stress, uniformly distributed load (udl). $* * *$

\section{INTRODUCTION}

The importance of concrete is widely seen in its used in construction work and for the foundation of most infrastructures. Its large use can be traced to being readily available and its suitable building properties such as the ability to support large compressive loads. However, the use of concrete is limited because it's low tensile strength. For this reason, reinforcement was introduced to take care of the tension that develops in concrete and one of the most popular of reinforcing bars (rebar) is steel. Steel has a relatively high tensile strength hence, complementing the low tensile strength of concrete. It is available and affordable in most developed countries but unfortunately the reverse is the case in developing and underdeveloped parts of the world like Nigeria. The high cost and low availability of Construction materials has lead researchers to sort for alternative materials for construction in other to provide affordable houses for dwelling. According to Job, Matawal and Achuenu (2009)[1], such alternative materials include sawdust, palm-kernel shell, olive seed, and periwinkle shell which can be used to either partially or fully replace aggregate(s) in concrete.

However, as the demand for concrete structures increases geometrically, there has been a corresponding decrease in the availability of concrete construction materials and a corresponding increase in the cost of the materials.

It is against this background that researches have been carried out to identify other suitable materials, affordable and readily available to either serve as total or partial replacement for steel and coarse aggregate in concrete works.

In the quest to finding an alternative to steel reinforcement, there have been researches on the use of geogrid, Muda, Sharif, and Hong (2012)[2]; bamboo, Brink and Rush (1966)[3], cane, Anioke, Okoro, Maduh, and Madubueze (2007)[4] etc as reinforcement materials but the use of other locally available sticks has received little attention. Over the 
years, "Owa" stick, (Jaundea Pinnata) has been used in the southern part of Nigeria (Akwa Ibom state) in reinforcing mud or earthen houses and it has proven to be a good construction material, hence, the need to study its performance as reinforcement in concrete slab. According to H.M. Burkill, in the book "Useful plants of west tropical Africa ( 2 nd edition) [5], Jaundea Pinnata belongs to the family of Connaracae, a shrub of $6-7 \mathrm{~m}$ tall, or lianescent to the forest canopy. Widely dispersed from Guinea to South Nigeria, and unto Angola and North-East and East Africa

In one of the communities in Akwa Ibom State, it was stated that over the years, owa stick otherwise known as Emong has been used for reinforcing mud or earthen houses because of its high durability. They went further to explain that once owa stick is dry, it doesn't absorb moisture again which gives it an advantage over bamboo. According to Ghavami (2005), bamboo is vulnerable to environmental degradation and attacks by insects and moulds [6]. There is a strong relation between insect attacks and the levels of starch plus humidity content of bamboo culm. In order to reduce the starch content, bamboo receives a variety of treatments including curing on the spot, immersion, heating or smoke, Ghavami (2005). According to the riverine dwellers, owa stick stays for years inside the walls of the house without being attacked by rodent or moulds because of its little or no starch and moisture content. Also, they concluded that it has high tensile strength when compared with bamboo.

Periwinkles (Nodilittorina radiata) are small greenish blue marine snails with spiral conical shell and round aperture, Adewuyi and Adegoke (2008) [7]. The average periwinkle lives three years and grows to a shell height of $20 \mathrm{~mm}$, but the largest recorded winkle grew to $52 \mathrm{~mm}$. They are common in the riverine areas and coastal regions of Nigeria where they are used for food. The hard shells, which are regarded as wastes ordinarily posed environmental nuisance in terms of its unpleasant odour and unsightly appearance in open-dump sites located at strategic places, are now being considered as coarse aggregates in full or partial replacement for expensive, unaffordable or unavailable crushed stones or local washed gravels. Periwinkle shells have been used by the people of the coastal states e.g. Rivers State of Nigeria for over 30 years as conglomerate in concrete reinforcement. These shells have been used for many purposes e.g. for homes, soak-away, slabs and road construction. The cost of these shells was more than 10 times cheaper than that of gravel as at the time of this study, Agbede and Mamasseh, (2009) [8].

Since Owa stick and periwinkle shell are naturally occurring materials common to the riverine areas of Nigeria, positive information obtained from this study on the flexural strength of Owa reinforced grano-periwinkle concrete slab will go a long way in minimizing the dependency on steel and granite as reinforcement material and aggregate for concrete slab respectively. Also, it will contribute immensely to housing delivery, especially in the riverine areas of Nigeria where these materials are abundantly available. Hence, if members made from these materials should posses' commensurable flexural strength with that of its counterpart, the study can guarantee its use as alternative materials for lightweight concrete constructions especially in areas where the weight of the structure is of great concern.

\section{MATERIALS AND METHODS}

\subsection{Selection of Materials}

The materials used in this research work were cement, water, sharp sand, granite, periwinkle shell, 6mm high yield steel, and $8-10 \mathrm{~mm}$ owa stick. The type of binder or cement used for this research was ordinary Portland cement from Ibeto in conformity with the requirements of BS 12 (1978) [9]. For the mixing of the concrete into paste, the water used was borehole water gotten from a tap in Federal Polytechnic, Nekede, Owerri, Imo State. The fine aggregate used in this work was sharp sand gotten from Otamiri River in nekede, Owerri. The sand was free from deleterious materials.

The coarse aggregate used in this research work included $20 \mathrm{~mm}$ granite. It was a normal weight aggregate gotten from the local market in Owerri, Imo State. It was free from debris. The Periwinkle shells were also used as coarse aggregate in this study. It was gotten from a stock pile in Abak, Akwa Ibom State, where it is wash dried and kept for buyers. It was free from deleterious matters. $6 \mathrm{~mm}$ high yield steel was used as reinforcement for the concrete slabs as control for the Owa stick reinforced concrete slabs. It was gotten from the local market in Owerri. Owa stick, Juandea Pinnata, was carefully cut from the bush in Umuchima, Imo State, with a diameter of $8-10 \mathrm{~mm}$ in size. The stick was carefully peeled and dried before cutting into $450 \mathrm{~mm}$ of length. This was done in other to take care of any decrease in size due to dehydration. The stick was then treated by soaking it in a solution of sodium chloride $(\mathrm{NaCl})$ for 12 hours in order to kill any inherent rodent. It was later steamed for 24 hours to remove the inherent cellulose from the stick. Finally, the stick was sun dried and used for reinforcement of the slab. The reinforcement sticks were arranged with the aid of binding wire and in two sets. The spacing used was same for both the main and distribution reinforcement. The two sets of reinforcements were spaced at $150 \mathrm{~mm}$ and $90 \mathrm{~mm}$ centre to centre.

\subsection{Mix Proportion, Casting of Cubes and Slabs}

A constant mix ratio of 1:2:2 and a water-cement ratio of 0.5 were maintained throughout this work. Batching operation was done by volume because of the nature of periwinkle shells. The fine aggregate used was sharp sand. Cast iron mould of size $150 \times 150 \times 150 \mathrm{~mm}$ was used in casting concrete cubes while wooden mould of 500x500x100mm was used in casting the concrete slabs. 
Sieve analysis was carried out on sharp sand, periwinkle shells and crushed granite using sieves arranged in decreasing size of opening. The fraction retained on each sieve size was weighed and recorded. Slump and water absorption test were also carried out on samples.

The cube mould was assembled prior to mixing and properly lubricated for easy removal of hardened concrete cubes. The wooden mould was properly covered with polyethene to enhance easy removal and to avoid loss of mixing water to the surrounding. The percentage by volume of crushed granite to periwinkle shells as coarse aggregate was 50:50. The mixing surface was soaked with water two hours prior to concrete mixing to saturate the surface against absorbing mixing water. The mixture was properly turned with shovel until it reached a plastic state which was fed into the moulds. Water curing method was adopted in this project. The specimens were made in accordance with BS 1881[10].

The molded concrete slabs and cubes were kept for 24 hours to set before demoulding. They were then fully immersed into a large curing tank filled with pipe borne water in order to increase the strength of the concrete, promote hydration, eliminate shrinkage and absorb heat of hydration until the age of test. The specimens were cured for 28 days. Prior to testing, the specimens were brought out of the curing tank and air dried for about 2 hours before crushing. The cubes were weighed before testing and the densities of cubes at the time of testing were measured. The compressive strengths of the cubes were tested in accordance to BS 1881 using universal testing machine. The slab was simply supported (SSSS) on all the four sides by steel beams of 50x500mm surface area.

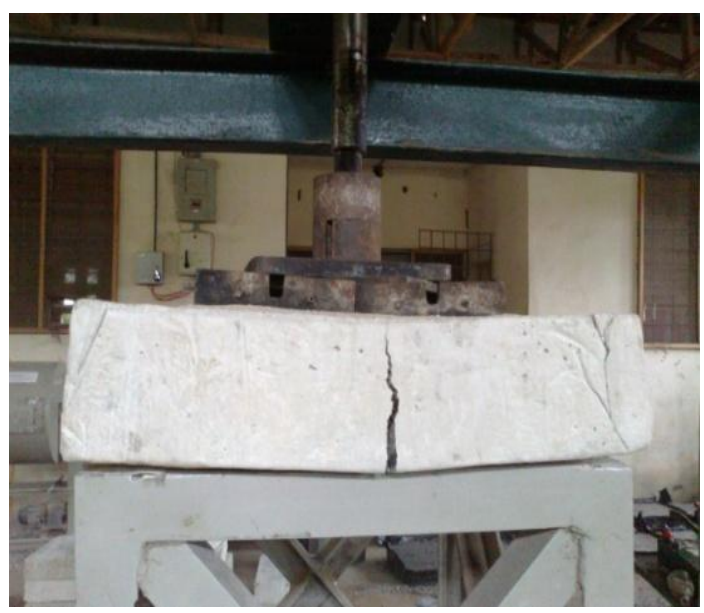

Fig-1: slab under uniformly distributed load.

The slab was loaded with uniformly distributed load over $380 \times 380 \mathrm{~mm}$ area at the center. The load was transferred from the $30 \mathrm{~mm}$ diameter plunger to the slab through the help of a metal plate and a sand bed to aid in load distribution (fig. 1).
Loading was done gradually at about one minute interval between each thrust; this was to aid in giving time for proper distribution of load in the member. The load was increased until the specimen failed according serviceability limit state, and the maximum load applied to the specimen during the test was recorded. The slab was considered to have failed once there was a visible crack greater than $0.3 \mathrm{~mm}$ at the bottom fiber according to Bs 8110-2:(1985) [11].

\section{RESULTS AND ANALYSIS}

From the grain size analysis data for sharp sand, granite and periwinkle shell, it was observed that aggregates were well graded (chart $1,2,3$ ). At a water-cement ratio of 0.5 , the slump was found to be $18 \mathrm{~mm}$. table 2 shows the density of cubes after 28days curring.

The density of the concrete resulting from a 1:1 granoperiwinkle aggregate was $2617.48 \mathrm{~kg} / \mathrm{m} 3$. According to BS, normal weight concrete is those with density of 2200 to $2600 \mathrm{~kg} / \mathrm{m} 3$. Therefore, grano-periwinkle concrete at $1: 1$ can be classified as structural normal weight concrete.

The 28-day compressive strength tested from the cubes gave strength of $19.932 \mathrm{~N} / \mathrm{mm} 2$, which is close to what was gotten by Osarenmwinda and Awaro (2009) [12] in similar mix. According to ACI 213 (1987), structural lightweight aggregate concrete is a concrete whose 28-day compressive strength is equal to or greater than $17 \mathrm{~N} / \mathrm{mm} 2$ [13] and also ASTM-C330 recommended minimum strength of $17 \mathrm{~N} / \mathrm{mm} 2$ for structural lightweight concrete [14]. Hence, it can be seen that compressive strength is not enough factor to use in classifying concrete, being that its density qualifies it for another group. Also, the strength of each set of slab specimen was determined by the number of reinforcement hence, the reduction in maximum flexural strength between $90 \mathrm{~mm}$ and $150 \mathrm{~mm}$ spaced reinforced slabs. 
Table 1: Densities of samples

\begin{tabular}{|l|l|l|l|}
\hline SPECIMEN & $\begin{array}{l}\text { SATURATED WET } \\
\text { Kg/m3 }\end{array}$ & $\begin{array}{l}\text { SATURATED } \\
\text { Kg/m3 } 3\end{array}$ & $\begin{array}{l}\text { SATURATED SURFACE } \\
\text { DRY Kg/m3 }\end{array}$ \\
\hline I & 2580.74 & 2571.85 & 2562.96 \\
\hline II & 2554.07 & 2539.26 & 2524.44 \\
\hline III & 2675.56 & 2663.70 & 2651.85 \\
\hline IV & 2500.74 & 2491.85 & 2477.04 \\
\hline V & 2554.07 & 2542.22 & 2524.44 \\
\hline VI & 2841.48 & 2823.70 & 2814.81 \\
\hline VII & 2459.30 & 2441.48 & 2429.63 \\
\hline VIII & 2764.44 & 2752.59 & 2737.78 \\
\hline IX & 2758.52 & 2743.70 & 2728.89 \\
\hline X & 2749.63 & 2731.85 & 2722.96 \\
\hline
\end{tabular}

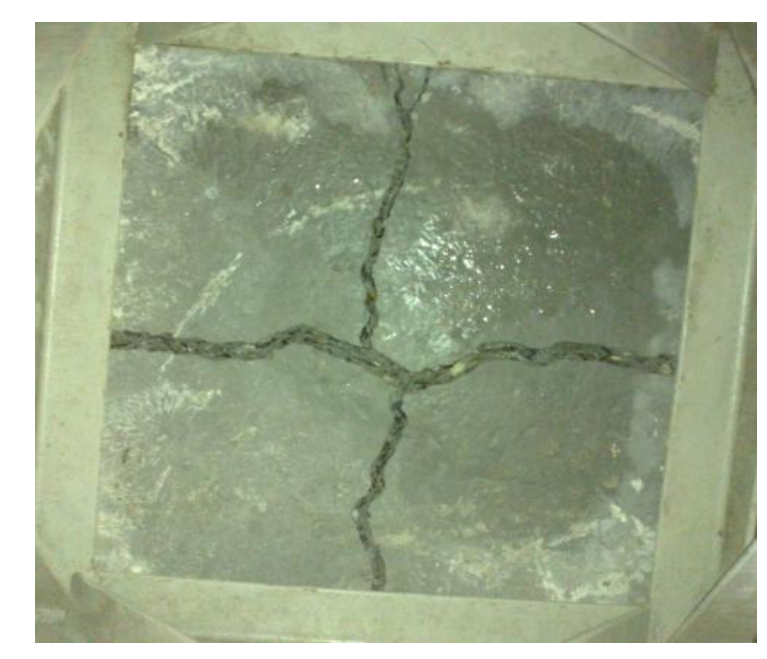

Fig 2: pattern of failure of slab subjected to uniformly distributed load

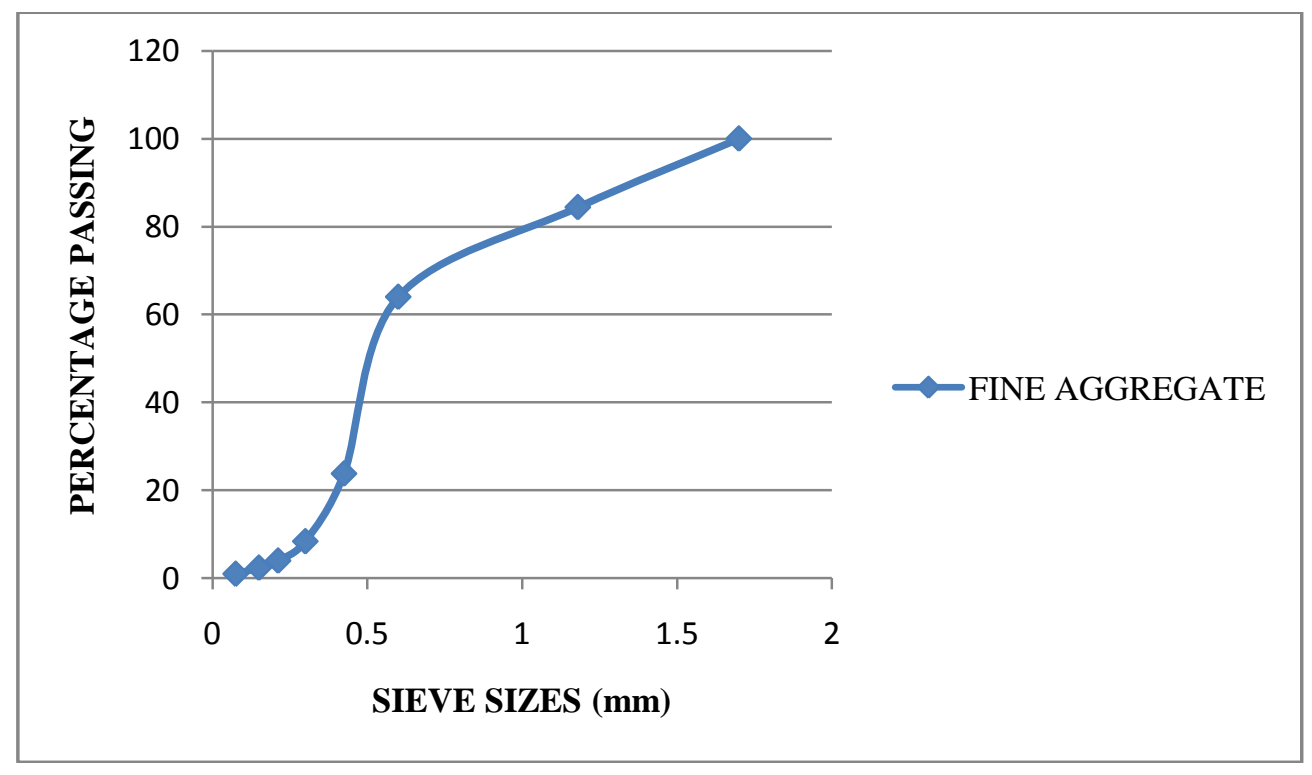

Chart-1: Grain size analysis graph for fine aggregate. 


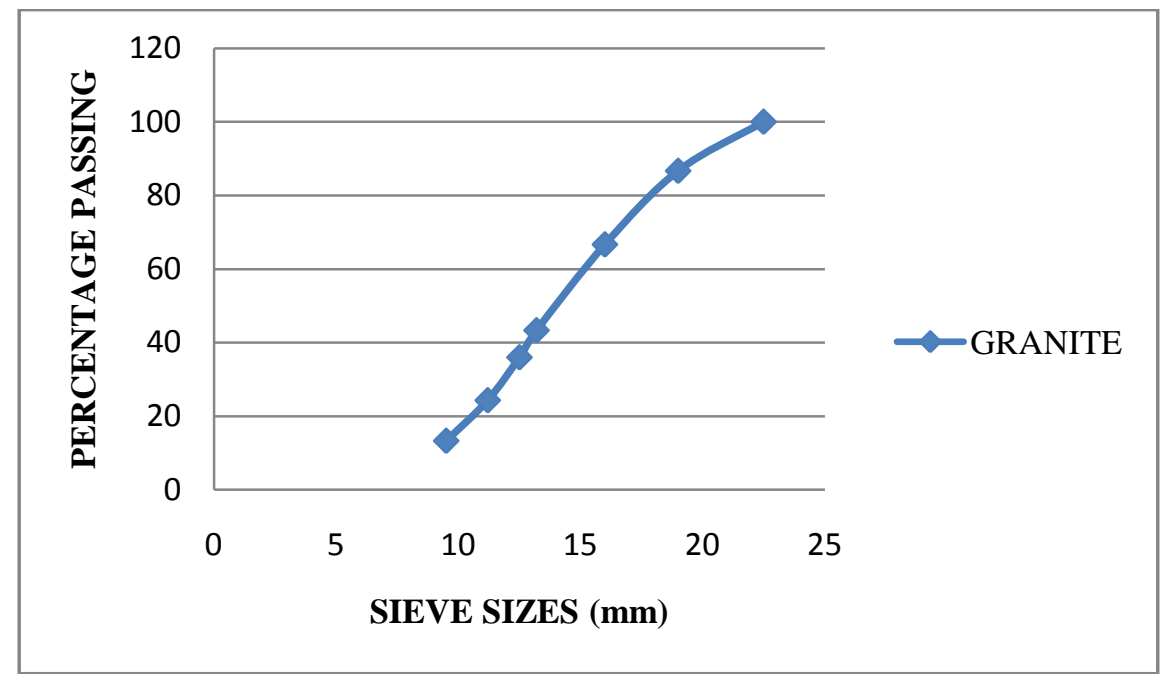

Chart-2: Grain size analysis graph for coarse aggregate (granite).

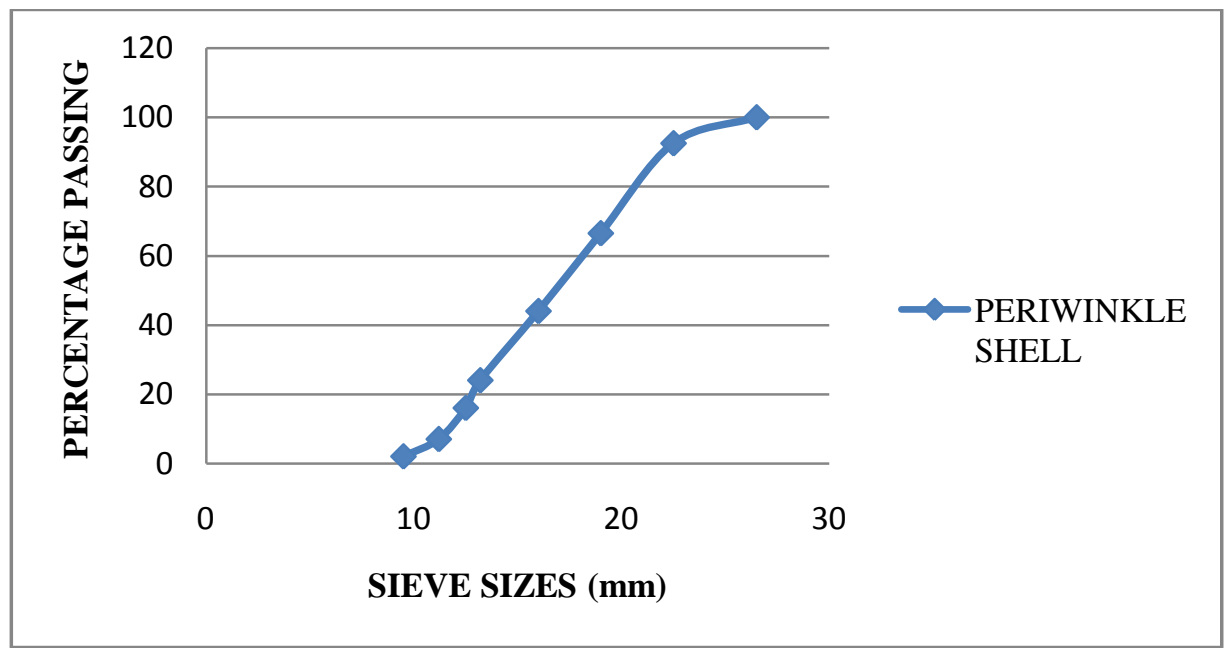

Chart-3: Grain size analysis graph for coarse aggregate (periwinkle).

Figure 2 shows the pattern of failure of grano-periwinkle slab when subjected to uniformly distributed load. The crack in both direction shows that the stress from the load was evenly distributed to all parts of the member. On testing the samples under uniformly distributed load, the steel reinforced slab showed high flexural strength and on failure, minimal cracks and crack width were obtained compared to stick reinforced and plain concrete slabs. Similarly, stick reinforced slabs failed with smaller crack width compared to plain concrete. The stick could be classified as ductile material based on its elastic performance in concrete. When loaded, just before failure point, once the load was removed or reduced, the slab completely recover and returns to its original shape and size; showing the elastic behavior of owa stick as reinforcement. For plain concrete, at the point of failure, the slab fails without any sign showing that is a brittle material with little or no tensile strength. From the results, it was seen that owa stick reinforced concrete was able to carry more amount of tension and did not have brittle failure when compared to plain concrete. From the results, at $90 \mathrm{~mm} \mathrm{c/c} \mathrm{spacing} \mathrm{of} \mathrm{owa} \mathrm{stick}$ reinforcement, the gain in stress of owa stick reinforced slab over plain slab was $25.30 \%$ while at $150 \mathrm{~mm} \mathrm{c} / \mathrm{c}$ spacing, there was a reduction in stress for about $-16.87 \%$. This showed that at $150 \mathrm{~mm}$ spacing, the slab was under-reinforced, hence, the owa stick tend to become a weakness to the slab by causing a discontinuity in the concrete matrix such that the slab failed under a smaller load than the plain concrete slab. The reduction can be attributed to the inadequacy of the reinforcement bars and large bar spacing. Moreover, when compared with steel reinforced slab, it showed that owa stick reinforced slabs had $57.14 \%$ and $43.67 \%$ strength of steel reinforced at $90 \mathrm{~mm}$ and $150 \mathrm{~mm}$ respectively. 
Table 2: failure load of concrete slabs reinforced with owa stick, steel, and plain subjected to uniformly distributed load.

\begin{tabular}{|l|l|l|l|l|l|l|}
\hline $\begin{array}{l}\text { SLAB } \\
\text { REINFORCEMENT } \\
\text { @ 90mm c/c }\end{array}$ & MARK & $\begin{array}{l}\text { LOAD } \\
(\mathbf{B a r})\end{array}$ & $\begin{array}{l}\text { LOAD } \\
(\mathbf{K N} / \mathbf{m} 2)\end{array}$ & $\begin{array}{l}\text { LOAD } \\
(\mathbf{K N})\end{array}$ & $\begin{array}{l}\text { LOAD } \\
(\mathbf{K N} / \mathbf{m})\end{array}$ & $\begin{array}{l}\text { AVGERAGE } \\
\text { LOAD }\end{array}$ \\
\hline \multirow{3}{*}{ STICK } & $\mathrm{A} 1$ & 74 & 7400 & 5.232 & 36.23 & \\
\cline { 2 - 8 } & $\mathrm{A} 1$ & 68 & 6800 & 4.808 & 33.30 & 33.947 \\
\cline { 2 - 8 } & $\mathrm{A} 1$ & 66 & 6600 & 4.666 & 32.31 & \\
\hline \multirow{3}{*}{ STEEL } & $\mathrm{B} 1$ & 126 & 12600 & 8.908 & 61.69 & \\
\cline { 2 - 8 } & $\mathrm{B} 1$ & 118 & 11800 & 8.343 & 57.78 & 59.407 \\
\cline { 2 - 7 } & $\mathrm{B} 1$ & 120 & 12000 & 8.484 & 58.75 & \\
\hline \multirow{2}{*}{ PLAIN } & $\mathrm{C}$ & 55 & 5500 & 3.889 & 26.93 & \\
\cline { 2 - 7 } & $\mathrm{C}$ & 57 & 5700 & 4.030 & 27.91 & 27.093 \\
\cline { 2 - 7 } & $\mathrm{C}$ & 54 & 5400 & 3.818 & 26.44 & \\
\hline
\end{tabular}

Table 3 failure load of concrete slab reinforced with owa stick, steel, and plain subjected to uniformly distributed load

\begin{tabular}{|l|l|l|l|l|l|l|}
\hline $\begin{array}{l}\text { SLAB } \\
\text { REINFORCEMENT } \\
\text { @ 150mm c/c }\end{array}$ & MARK & $\begin{array}{l}\text { LOAD } \\
\text { (Bar) }\end{array}$ & LOAD $(\mathbf{K N} / \mathbf{m} 2)$ & $\begin{array}{l}\text { LOAD } \\
(\mathbf{K N})\end{array}$ & $\begin{array}{l}\text { LOAD } \\
(\mathbf{K N} / \mathbf{m})\end{array}$ & $\begin{array}{l}\text { AVG. } \\
\text { LOAD }\end{array}$ \\
\hline \multirow{3}{*}{ STICK } & $\mathrm{A} 2$ & 43 & 4300 & 3.040 & 21.05 & \\
\cline { 2 - 7 } & $\mathrm{A} 2$ & 45 & 4500 & 3.182 & 22.04 & 22.523 \\
\cline { 2 - 7 } & $\mathrm{A} 2$ & 50 & 5000 & 3.535 & 24.48 & \\
\hline \multirow{3}{*}{ STEEL } & $\mathrm{B} 2$ & 108 & 10800 & 7.636 & 52.88 & \\
\cline { 2 - 7 } & $\mathrm{B} 2$ & 102 & 10200 & 7.211 & 49.94 & 51.573 \\
\cline { 2 - 7 } & $\mathrm{B} 2$ & 106 & 10600 & 7.494 & 51.90 & \\
\hline \multirow{3}{*}{ PLAIN } & $\mathrm{C}$ & 55 & 5500 & 3.889 & 26.93 & \\
\cline { 2 - 7 } & $\mathrm{C}$ & 57 & 5700 & 4.030 & 27.91 & 27.093 \\
\cline { 2 - 7 } & $\mathrm{C}$ & 54 & 5400 & 3.818 & 26.44 & \\
\hline
\end{tabular}

Table4. Maximum flexural strength of slab samples

\begin{tabular}{|c|c|c|c|c|c|c|}
\hline $\begin{array}{l}\text { REINFORC. } \\
\text { SPACING } \\
(\mathrm{mm}) \mathrm{c} / \mathrm{c}\end{array}$ & $\begin{array}{l}\text { TYPE } \\
\text { RINFR. }\end{array}$ & $\begin{array}{l}\text { FAILURE } \\
\text { LOAD, KN }\end{array}$ & $\begin{array}{l}\text { MAX. } \\
\text { MOMENT } \\
\text { KNm }\end{array}$ & $\begin{array}{l}\text { MAX. } \\
\text { FLEXURAL } \\
\text { STRESS } \\
\text { KN/m2 }\end{array}$ & $\begin{array}{l}\text { \% GAIN IN } \\
\text { STRESS } \\
\text { OVER } \\
\text { PLAIN } \\
\text { CONCRETE }\end{array}$ & $\begin{array}{l}\text { OWA } \\
\text { REINFR. AS } \\
\text { A \% OF } \\
\text { STEEL } \\
\text { REINFR. } \\
\text { CONCRETE }\end{array}$ \\
\hline \multirow{3}{*}{90} & STICK & 33.947 & 1.2133 & 485.32 & \multirow{3}{*}{25.30} & \multirow{3}{*}{57.14} \\
\hline & STEEL & 59.407 & 2.1232 & 849.31 & & \\
\hline & PLAIN & 27.093 & 0.9683 & 387.34 & & \\
\hline \multirow{3}{*}{150} & STICK & 22.523 & 0.8050 & 322.00 & \multirow{3}{*}{-16.87} & \multirow{3}{*}{43.67} \\
\hline & STEEL & 51.573 & 1.8432 & 737.31 & & \\
\hline & PLAIN & 27.093 & 0.9683 & 387.34 & & \\
\hline
\end{tabular}

The following formulae were used in calculating for various parameters;
Where, $R$ and $Q$ are dimensionless quantities; $R$ $=x / a$ and $Q=y / b ; a=b=0.5 m$

From plate theory, using polynomial shape function, the displacement function for ssss plate is;

$W=A\left(R-2 R^{3}+R^{4}\right) \cdot\left(Q-2 Q^{3}+Q^{4}\right) \quad \ldots \ldots \ldots \ldots 1$ 
From Ritz energy equation

$$
\begin{aligned}
\Pi=\frac{a b D}{2 b^{4}} \iint_{0}^{1}\left[\frac{1}{P^{4}}\right. & \left(\frac{\partial^{2} W}{\partial R^{2}}\right)^{2}+\left(\frac{\partial^{2} W}{\partial Q^{2}}\right)^{2} \\
& \left.+\frac{2}{P^{2}}\left(\frac{\partial^{2} W}{\partial R \partial Q}\right)^{2}\right] \partial R \partial Q-a b q \iint_{0}^{11} w \partial R \partial Q
\end{aligned}
$$

substituting the appropriate differential and integral form of equation 1 into Ritz energy method,

the parameter A, gives;

$$
A=\frac{0.04236 b^{4} q}{D}
$$

From plate theory, moment, $M$, is given by;

$$
\begin{aligned}
& M_{x}
\end{aligned}
$$

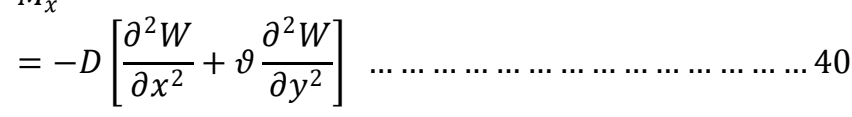

$$
\begin{aligned}
& M_{y}=-D\left[\vartheta \frac{\partial^{2} W}{\partial x^{2}}\right. \\
& \left.+\frac{\partial^{2} W}{\partial y^{2}}\right]
\end{aligned}
$$

For a square plate, $M_{x}=M_{y}$; and $\vartheta=$

0.2 (clause 2.4.2.4, BS 8110)

For ssss plate, maximum moment at the centre is;

$M_{R}=M_{Q}$

$=0.047655 b^{2} q$

Maximum flexural stress, $\partial=\frac{6 M}{b h^{2}}=14.2965 q$

where $h=0.1 \mathrm{~m}, a=b=0.5 \mathrm{~m}$

The percentage water absorption of periwinkle shells and granite was 4 and 0.4 respectively. This is in-line with Ibearugbulem (2006) [15]. However, the water absorption value of periwinkle shell is different from that reported by Job, Matawal and Achuenu (2009) [1], but according to Oguara (1984), the varied absorption values could be due to the varied species available in West Africa [16].

\section{CONCLUSIONS}

From the test carried out on the stress resistance of owa stick reinforced grano-periwinkle concrete slab, the following conclusions can be drawn:
Granite-periwinkle concrete at a ratio of $1: 1$ in a mix of 1:2:2 can be classified as normal weight concrete because its density is greater than $2000 \mathrm{~kg} / \mathrm{m} 3$.

The strength of owa stick reinforced granite-periwinkle concrete slab is determined based on the properties of the shells; the percentage replacement and the quantity of owa stick reinforcements.

Owa stick has proven to be a good reinforcement material for concrete by providing $25.30 \%$ gain in stress resistance over plain concrete when spaced at $90 \mathrm{~mm} \mathrm{c} / \mathrm{c}$, and its elastic nature and durability has helped concrete not to have brittle failure.

Owa stick reinforced granite-periwinkle slab had strength of $57.14 \%$ and $43.67 \%$ when compared to steel reinforced at $90 \mathrm{~mm}$ and $150 \mathrm{~mm}$ reinforcement spacing respectively; which could be greater with increased number of reinforcement.

The percentage gain in stress of owa stick reinforced concrete can be enhanced by increasing the quantity of reinforcements.

The strength development in granite-periwinkle concrete is similar to those of the conventional granite concrete.

\section{REFERENCES}

[1]. Job F. O., Matawal, D. S. and Achuenu, E. (2009). The characteristics of periwinkle shell as an aggregate in concrete. Nigerian journal of construction technology and management 10(1\&2); 96-101

[2]. Muda, Z. V., Sharif, S. F., and Hong, Y. J. (2012). Flexural behavior of lightweight oil palm shells concrete slab reinforced with Geogrid. International journal of science and engineering research, 3(11)

[3]. Brink, F. E. and Rush, P. J. (1966). Bamboo reinforcement concrete construction U. S. Naval civil engineering laboratory, Port Hueneme, California

[4]. Anioke, C.N., Okoro, N.M, Maduh, U.J, and Madubueze, O.C. Effect of cane reinforcement on the modulus of rupture of cane reinforced concrete beam, Federal University of Technology, Owerri, Nigeria, (2007).

[5]. Burkill H. M. "Useful plants of West tropical Africa (2nd edition), Volume 1.Royal Botanic Gardens, Kew, London 1985.

[6]. Ghavami, K. (2005). Bamboo as reinforcement in structural concrete elements Elsevier Ltd, cement and concrete composites 27, 637-649

[7]. Adewuyi, A. P., and Adegoke, T. (2008). Exploratory study of periwinkle shells as coarse aggregates in concrete works. ARPN Journal of Engineering and Applied Sciences Vol. 3(6)

[8]. Agbede, O.I and Manasseh, J. (2009). Suitability of Periwinkle Shell as Partial Replacement for River Gravel in Concrete Leonardo Electronic Journal of Practices and Technologies.15 59-66 
[9]. British Standard Institution 12: (1996). Specifications for Portland cement London.

[10]. British Standard Institution 1881-108: (1983). Method of Testing Concrete London

[11]. British Standard Institution 8110-2: (1985). Code of practice for special circumstances London pp 9

[12]. Osarenmwinda, J.O. and Awaro, A. O. (2009). The potential use of periwinkle shell as coarse aggregate for concrete Journal of advanced materials research 62-64

[13]. ACI 213 (1987). Guide for structural lightweight aggregate concrete. ACI committee 213 Pp 38

[14]. ASTM C330 (1999). Standard Specification for lightweight aggregate concrete ASTM International, United States

[15]. Ibearugbulem, O. M. Mathematical models for optimization of compressive strength of periwinkle shellsgranite concrete. Unpublished master of engineering thesis, federal university of technology, owerri, Nigeria, 2006

[16]. Oguara, T. M. suitability of periwinkle shells as construction aggregates. Paper presented at the conference on Material Testing Control and Research, Portharcourt, Nigeria, 1984. 